\title{
Assessment of The Relationship Between Maternal Dietary Patterns During Pregnancy and its Outcomes in Infants
}

\author{
Zahra Karimi', Parvin Ayremlou ${ }^{2,}$ Sakineh Nouri Saeidlou ${ }^{3}$ \\ 1.MSc of Nutrition, Department of Nutrition Sciences, School of Medicine Urmia University of Medical Sciences, Urmia, \\ Iran. ORCID ID: 0000-0003-4042-7511 \\ 2. MSc of Epidemiology, Clinical Research Development Unit of Imam Khomeini Hospital, Urmia University of Medical \\ Sciences, Urmia, Iran. ORCID ID: 0000-0002-0006-013x \\ 3.Associate Professor, Departemant of nutrition, Food and Beverages Safety Research Center, Urmia University of Medical \\ Sciences, Urmia, Iran. (Corresponding author),Tel:04432766825, Email:nourisaeidlou_s@umsu.ac.ir, ORCID ID: 0000- \\ 0003-0302-8765
}

\begin{abstract}
Background and Aim: Pregnancy is a critical period for the offspring's metabolic development. Nutrition during pregnancy due to its role in the development of mental and physical abilities in infants is important. The current study aimed to determine the relationship between maternal dietary patterns during pregnancy and its outcomes in infants in Urmia city.

Materials and Methods: In this cross-sectional study, 410 pregnant women referred to health centers in Uremia were selected by cluster random sampling. Food information was collected using the validated 147-items Food Frequency Questionnaire (FFQ). The demographic information of mothers was collected by interview. Factor analysis was used to identify the major dietary patterns.

Results: In this study, three main dietary patterns were identified and named the first, second, and third groups. Multivariate logistic regression showed that the Low Birth Weight (LBW) and Preterm Birth (PTB) increased with adherence to the first dietary pattern (LBW: OR $=1.15$, PTB: OR=1.05), while the risk of Small for Gestational Age (SGA), $(\mathrm{OR}=0.89)$, and Large for Gestational Age (LGA), $(\mathrm{OR}=0.8)$ decreased in this pattern. The second dietary pattern was inversely associated with LBW $(\mathrm{OR}=0.73)$ and LGA $(\mathrm{OR}=0.83)$, While it was positively associated with PTB $(\mathrm{OR}=1.26)$ and SGA $(\mathrm{OR}=1.04)$. The third dietary pattern was inversely associated with all the above outcomes and this difference was significant for $\mathrm{LGA}(\mathrm{OR}=0.68)$.

Conclusion: The present study showed a relationship between LBW, SGA, PTB, LGA indices, and maternal dietary patterns during pregnancy. Prospective studies have been suggested to confirm these findings.
\end{abstract}

Keywords: Dietary pattern, Pregnancy, Low Birth Weight, Small for Gestational Age, Preterm Birth, Large for Gestational Age

Received: Aug 7, $2019 \quad$ Accepted: Nov 27, 2019

How to cite the article: Zahra Karimi' Parvin Ayremlou' Sakineh Nouri Saeidlou. Assessment Of The Relationship Between Maternal Dietary Patterns During Pregnancy And Its Outcomes In Infants.SJKU 2019;25(5):67-83.

Copyright (C) 2018 the Author (s). Published by Kurdistan University of Medical Sciences. This is an open access article distributed under the terms of the Creative Commons Attribution-Non Commercial License 4.0 (CCBYNC), where it is permissible to download, share, remix, transform, and buildup the work provided it is properly cited. The work cannot be used commercially without permission from the journal 


\section{بررسى ارتباط بين الكو هاى غذايى مادر در طول باردارى و بيامدهاى آن در نوزادان}

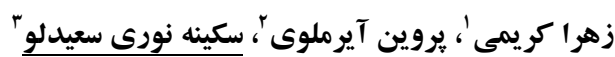

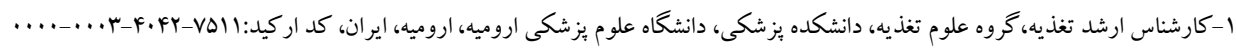

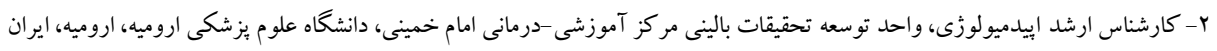

كد اركيد:

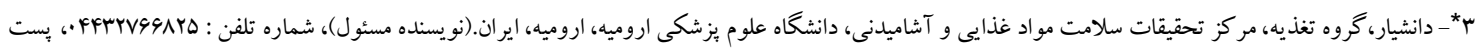

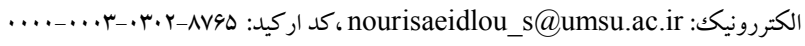

جكيله زمينه وهدف : باردارى يكك دوره بحر انى براى رشد متابوليك فرزندان مى باشد. تغذيه در دوران باردارى به علت نقشى كه در

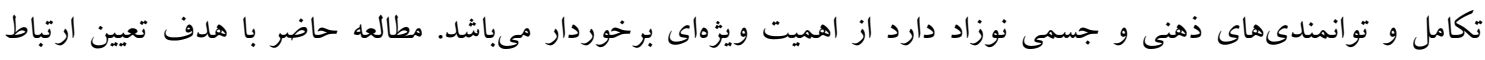

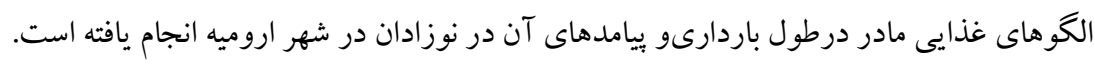

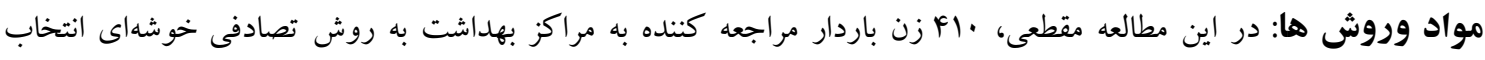

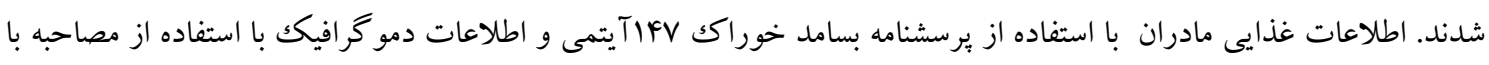
مادران جمع آورى شد. جهت شناسايى الكوهاى غذايى غالب از آناليز تحليل عاملى استفاده شد.

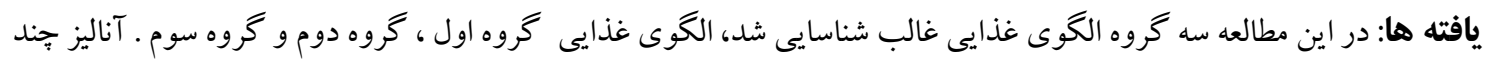

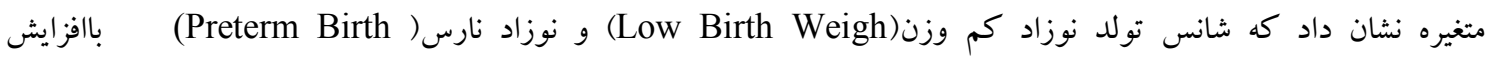

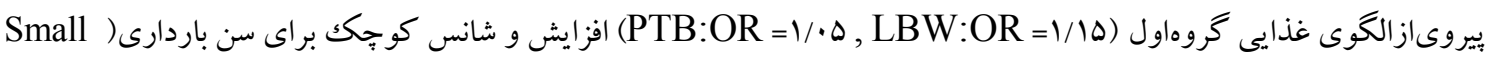
/^ , LGA:OR= •/^q) (Larg for Gestational Age (for Gestational Age OR=./NFA:OR=

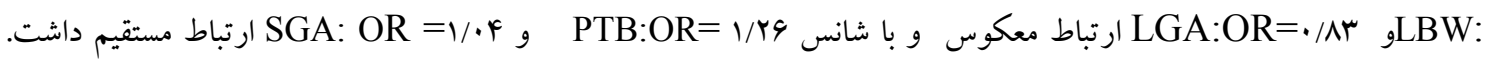

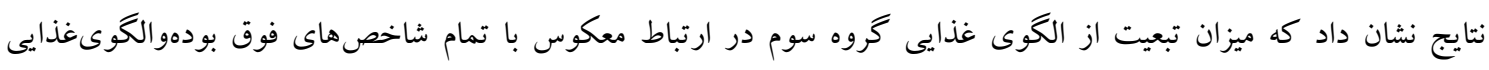

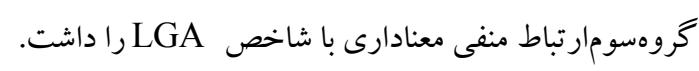

نتيجه كيرى: مطالعه حاضر وجود ارتباط بين شاخص هاى LBW ,SGA ,PTB ,LGA و الكوهاى غذايى ماردي مادر در طول

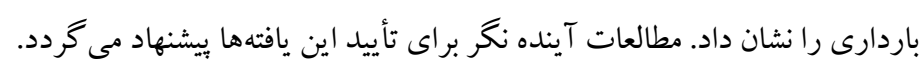

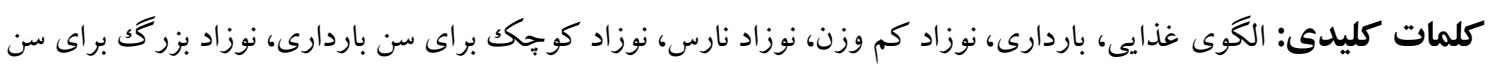

باردارى

وصول مقاله :9/1/4/9 اصلاحيه نهايى:9/9/19 بذيرش:9N/1Y/9 
يامد تطابق با شرايط محروميت غذايى در زندگى جنينى ميباشد(IV). بنابراين يرداختن به كميت و كيفيت تغذيه در

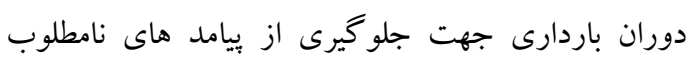
عنوان شده از اهميت ويزه اى برخوردار مىباشد. الكوى غذايى رفتارهاى غذايى يكك جمعيت از طريق تجزيه وتحليل گروه هاى غذايى ومواد مغذى ويك متد بيجِيده از عمل خوردن است كه اجزا وتر كيبات مختلف از يكك وعده غذايى رادر نظر مى گيرد(1)). در واقع الخُوهاى غذايى هر فرد نه تنها شيوه زندگى رزيمى آن فرد را مشخص مى كند(f (f). بلكه تعاملات مثبت ومضر مواد مغذى در غذاهاى مختلف مصرف شده همراه با منابع مختلف غذايى از ماده

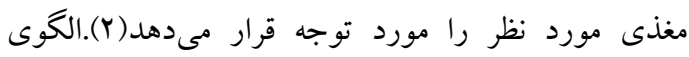
غذايى به سه صورت قابل تعريف ومحاسبه است:ا-نمره

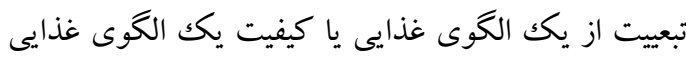

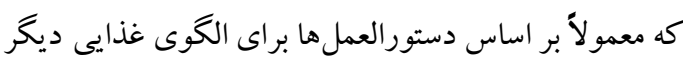
تعريف مىشود.r-- رابطه بين گرووهاى غذايى با استفاده از آناليز خوشهاى ودر نظر گرفتن اجراى اصلى در جمعييتى از مردم كه بر اساس دريافت غذايى طبقه بندى مىشوند.ب- به صورت يكك رابطه خطى بين دريافت يك ماده مغذى با يك شاخص از بيمارى بر اساس تحليل عاملى (اندازهگيرى بيشترين واريانس ارنباط بين اجزاى غذا با يك متغير )

$$
\text { تعريف مىشود (19). }
$$

محققين در اغلب مطالعات انجام يافته به بررسى رابطه بين يكك ماده غذايى يا تعداد كمى از غذاها يا ريز مغذىها با ييامدهاى آن يرداختهاند. از آنجا كه غذاها به صورت مجزا مصرف نمىشوند و به صورت تركيب هستند، بس بايد الخوى غذايى براى غذاى مصرفى در نظر گرفته

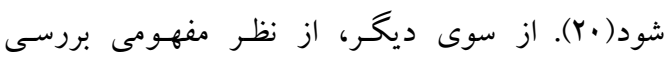
الكوهـاى غذايى بـه واقعيـت نزديـكتـر اسـت، زيـرا مـردم مواد مغذى را بـه صسورت تفكيكك شـده دريافت نمسى كننـد و تغذيـه آنها از غـذاهاى مختلـف بـا تركيب متفاوتى از مواد مغذى تشكيل شـده اسـت كه مىتواند
مقدمه

باردارى يكك دوره حياتى براى رشد متابوليك فرزندان مىباشد (1). مسائل و مخاطرات گوناگونى بر روند باردارى تأثير گذار بوده و قابل ارزيابى است. يكى از اين مسائل مهم تغذيه است(Y). باردارى يكك دوره حساس و و مهم در زندكى زنان است و با افزايش نيازهاى تغذيهاى در آنان همراه است(r). سؤتغذيه در دوره باردارى موجب عوارض متعدد در مادر و جنين ميخردد(F). كهازآن جمله

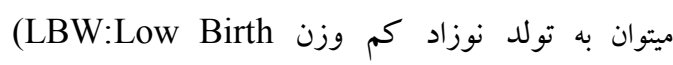

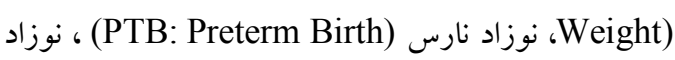
كوجֶ (SGA: Small for براى سن باردارى Gestational Age) زايمان سزارين و لواي (LGA: Larg for Gestational Age) ساير عوارض مربوط به باردارى مثل ديابت باردارى، فشارخون و وِرهاكلاميسى اشاره كرد(9-ه). تغذيه دوران باردارى همجنين يكك عامل مهم در كاهش خطر مرگك و مير مربوط به باردارى مىباشد(ه). وزن نوزاد يكى از مهمترين شاخصها براى زنده ماندن و سلامت كودكك در

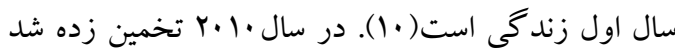
كه سالانه ..

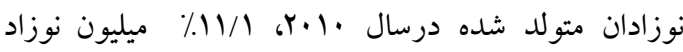

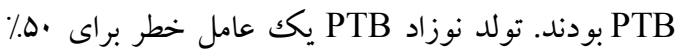
از مرگك و مير نوزادى است(r). سالانه 20 ميليون كودك LBW متولد مىشود(سا). قريب به VD٪ مركى

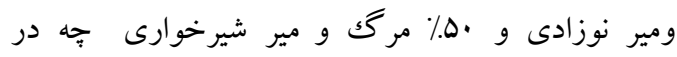
كشورهاى بيشرفته و جهه در كشورهاى در حال توسعه، در نوزادان LBW روى مىدهد LFA If). شيوع LGA در جهان

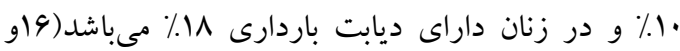
ها). نتايج مطالعات منعدد انجام شده در جهان حاكى از آن بود كه نوزادان ترمى كه براى سن حاملكى كوجّك

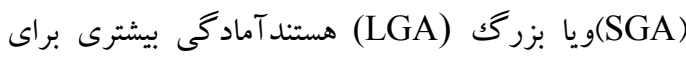

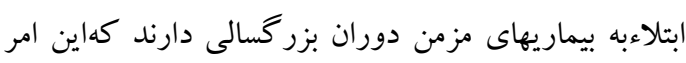


₹ D و E: Design Effect =1/ه) عدد P4 P4. P •). روش نمونه گيرى بصورت خوشهاى، دو مرحله اى تصادفى بود. در اين روش نمونه گيرى، ابتدا براى تمام مراكز بهداشتى يك كد داده شد و با استفاده از

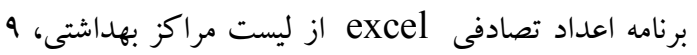
مركز بهداشتى بصورت تصادفى انتخاب ش شدند. سبس إنس

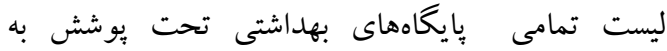
تفكيك مراكز بهداشتى استخراج شد. با توجه به درصد بإيخاههاى بهداشتى در هر مركز بهداشتى نسبت به كل بايخاهها، تعداد مورد نياز با توجه به حجم نمونه تعيين شده در هر مركز بهداشتى محاسبه شدو در نهايت از هر بايخاه بهداشتى افراد بصورت تصادفى انتخاب و وارد مطالعه شدند.

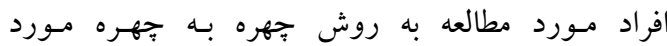
مصاحبه قرارگرفتند و مشخصات بايه اى از قبيل: سن، ميزان تحصيلات، وضعيت اقتصادى، شغل، تعداد باردارى، تعداد زايمانهاى قبلى، فاصله آخرين باردارى يا سقط با لياك باردارى فعلى، سابقه سقط، مرده زايى، تولد نوزاد كم

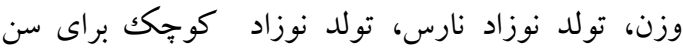
باردارى، تولد نوزاد بزرگك براى سن باردارى، ديابت و

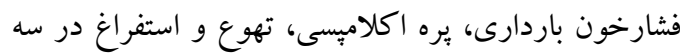
ماهه اوّل، مصرف الكل و استعمال دخانيات و ميزان

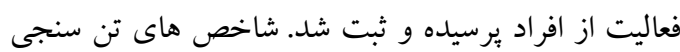

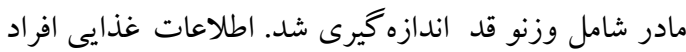

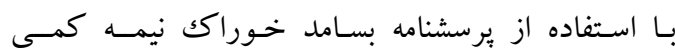
معتبر و و بايا شـامل IFV قلم ماده غذايى، براى يكك سال بال

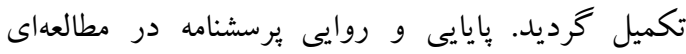
توسط ميرميران و همكاران تاييد شده است(YN). اندازه

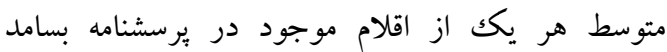

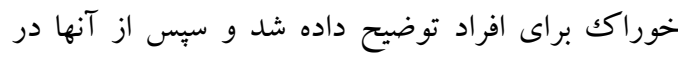

اثر تداخل و يـا هـم افزايسى روى همديخر داشته باشند. الكوهاى غذايى به طور معمول استفاده مىشوند و و بايد

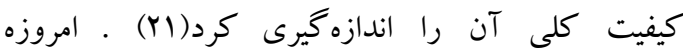
متخصصان علوم تغذيه به منظور بررسى تاثير كلى رزيم غذايى بر ييامدهاى سلامتى از تحليل الكوى غذايى استفاده ميكنند و جرنين تحليلى را بر ساير تحليل هاى سنتى ترجيح مى دهند(YY-YF). نظر بـهـ اهميـت فـوق العـاده تغذيـهـ در دوران باردارى و همجنين با توجه به اينكه تغذيه دوران باردارى مى تواند

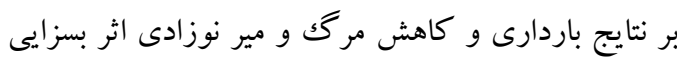
داشته باشد و با توجه به اينكه ساير مطالعات بيشين عمدتاً

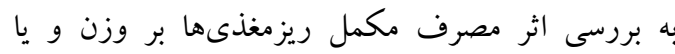

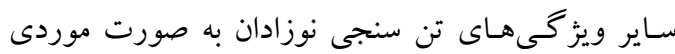
يرداختـه اند، لذا مطالعه حاضر بنابر جستجوهاى انجام يافته،براى اولين بار در ايران با هدف تعيين ارتباط بين

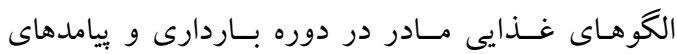
آن در نوزادان انجام گر فته است.

مواد وروش ها در مطالعه مقطعى حاضر جامعه مورد مطالعه شامل زنان

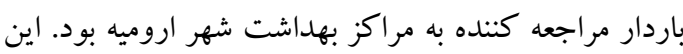

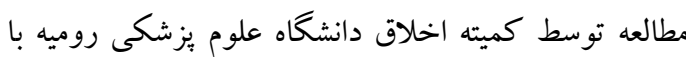
كد :IR.umsu.rec.1396.181 تأييد شده است. معيار هاى خروج شامل داشتن بيمارى قبل از باردارى مثل

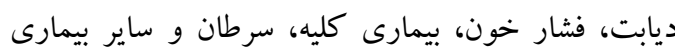
هاى مزمن يا عفونت مثل اختلالات اتوايميون، ايدز و

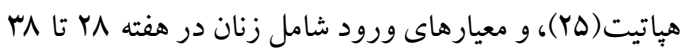

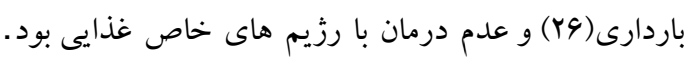

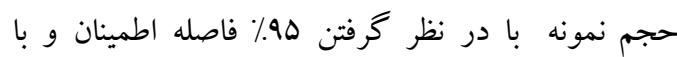

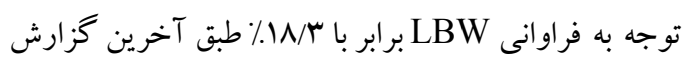

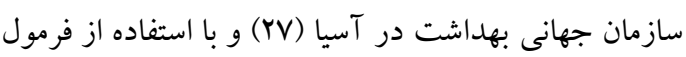


مواد مغذى يكك قلم غذايى تفاوت عمده اى با ساير اقلام

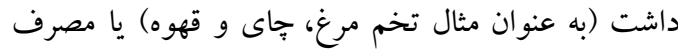
آن بيانگر عادت غذايى خاصى بود يكك گروه ران ما تشكيل

جهت شناسايى الكوهاى غالب از روش تحليل عاملى روى داده هاى حاصل از FFQ استفاده شد(•(1)به اين ترتيب كه روش تحليل مؤلفههاى اصلى PCA: Principal Component Analysis) كروه هاى غذايى به كار گرفته شده و تصميم گيرى در ارتباط با تعداد الكوهاى مهم غذايى بر اساس نماس نمودار Eigenvalue وScree عاملى بود. در اين بُزوهش مقدار بار عاملى براى تعيين كروه هاى غذايى در هر الكوى غذايى محاسبه شد (بار

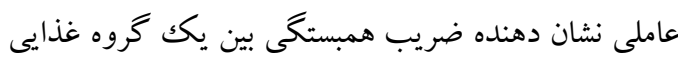

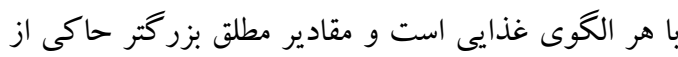

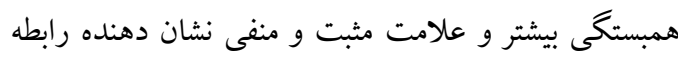

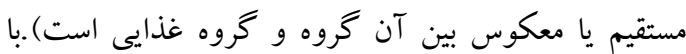
مشاهده بار عاملى اقلام غذايى بر مبناى مطالعات بيشين سه

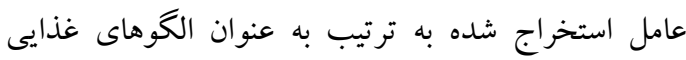

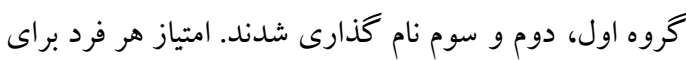

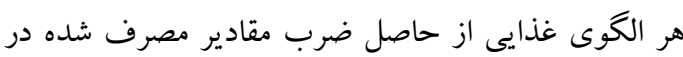

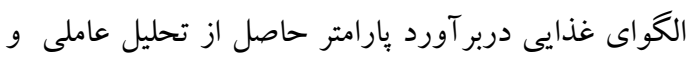

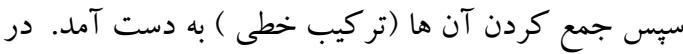

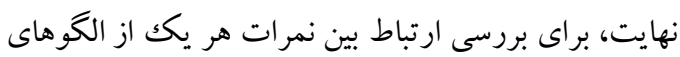

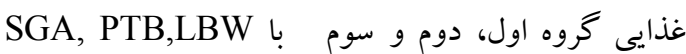

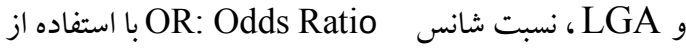

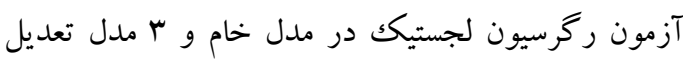
شده براى هر كدام از بيامدها محاسبه شد. در بررسى ارتباط

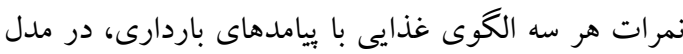

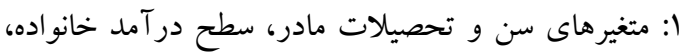
در مدل ז: علاوه بر متغيرهاى مدل ا، تعداد باردارى، تعداد زايمان، فاصله باردارى و نوع زايمان و در مدل rا: علاوه بر برك
مورد تكرر مصرف هر يكك از اقلام غذايى موجود در يرسشنامه در طول يكك سال گذشته سؤال شد. اطلاعـات

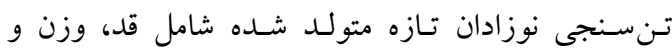
دور سر از طريق اطلاعات ثبت شده در سيستم اطلاعاتى

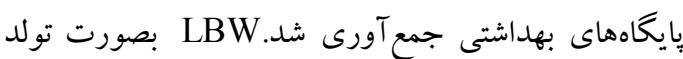

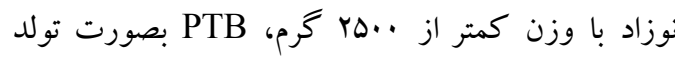

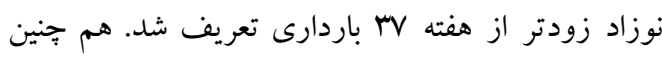
بصورت نوزاد باوزن تولد زير • •٪ وزن جامعه در آن سن بارورى و LGA بصورت تولد نوزاد با وزن هنكام

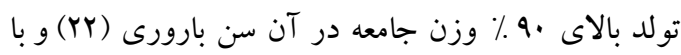
توجه به شاخصهاى تن سنجى نوزاد محاسبه شد. به اين

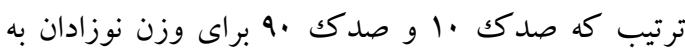

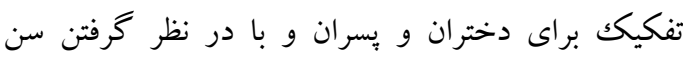

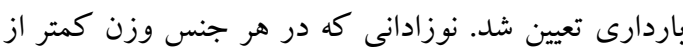

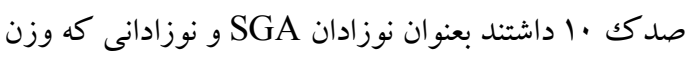

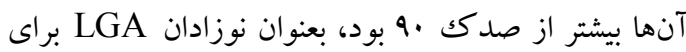
آن سن باردارى در نظر گرفنه شدند.

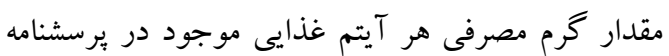

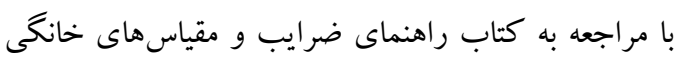
و با توجه به اندازه هر غذا استخراج شد و با توجه به به مقدار مصرفى آن توسط شركت كننده آن را در يورشن سايز ضرب كرده و بر Vروز هفته يا ·r روز ماه يا هون

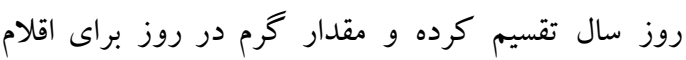
غذايى محاسبه شد.

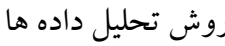
جهت شناسايى الكوهاى غذايى غالب از آناليز تحليل عاملى دادي استفاده شد. به علت تعداد زياد اقلام غذايى موجود در

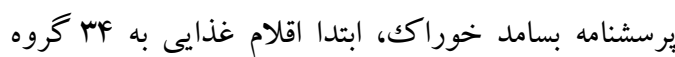

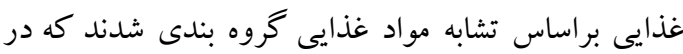

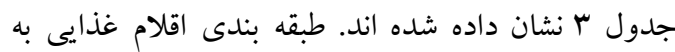

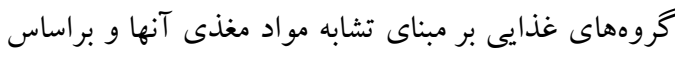

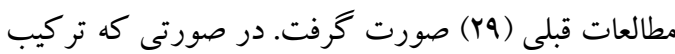


مشخصات دمو گرافيك زنان باردار در جدول ا و r نشان داده شده است . سن متوسط در زنان بr/YN/

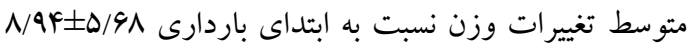
كيلو گرم بود. اقلام غذايى دسته بندى شده براى گروه هاى غذايى جهت آناليز تحليل عاملى در جدول r نشان داده

$$
\text { شده است. }
$$

متغيرهاى مدل Y، وزن مادر در ابتدا و آخر باردارى، نمايه توده بدنى و جنسيت نوزاد تعديل شده اند. تحليل آمارى در نرم افزار SPSS20 انجام شد. سطح معنى دارى در تمام آزمون ها كمتر از هـ • • در نظر كرفته شد.

جدول | : فراوانى و درصد فراوانى متغيرهاى كيفى در زنان باردار

\begin{tabular}{|c|c|c|c|}
\hline درصد & تعداد & & متغير \\
\hline $1 / Y$ & $\Delta$ & آزاد & اغل \\
\hline$r / q$ & ir & كارمند & \\
\hline $9 \Delta / 9$ & rar & خانه دار & \\
\hline$\Delta \cdot / r$ & r.9 & كمتر از يك ميليون & در آمد ماهيانه خانو اده \\
\hline kr & IVY & بين يك تا دو ميليون & \\
\hline$\Delta / 9$ & r & بين دو تا سه ميليون & \\
\hline$r / Y$ & 9 & بيشتر از سه ميليون & \\
\hline$|F /|$ & $\Delta \Lambda$ & ل & تحصيلات \\
\hline $91 / 0$ & ror & ابتدايى و راهنمايى & \\
\hline $10 / 4$ & 94 & دييلم & \\
\hline $\mathrm{V} / \mathrm{\Lambda}$ & rr & فوق دييلم و ليسانس & \\
\hline $1 / r$ & $\Delta$ & ارشد و بالاتر & \\
\hline$\Lambda r / F$ & MFY & كمتر از سه بار & تعداد باردارى \\
\hline $19 / 9$ & 91 & بيشتر و مساوى سه بار & \\
\hline $9 Y / Y$ & rVA & كمتر از دو بار & تعداد زايمان \\
\hline $\mathrm{V} / \mathrm{\Lambda}$ & rr & بيشتر از دو بار & \\
\hline $\mathrm{FV} / \mathrm{A}$ & 199 & كمتر از دو سال & فاصله باردارى \\
\hline$r / V$ & 19 & بين دو تا جهار سال & \\
\hline$r \cdot / \Delta$ & Iro & بيشتر و مساوى جهارسال & \\
\hline$r \cdot / r$ & $\wedge r$ & بله & سابقه سقط \\
\hline $\mathrm{Va} / \mathrm{A}$ & TrV & خير & \\
\hline$r / 9$ & 19 & بله & سابقه مرده زايى \\
\hline $99 / 1$ & raf & خير & \\
\hline$V / 9$ & r & بله & سابقه تولد نوزاد كم \\
\hline$Q Y / F$ & rva & خير & \\
\hline$r / r$ & 9 & بله & سابقه تولد نوزاد نارس \\
\hline $9 \mathrm{~V} / \mathrm{\Lambda}$ & $4 \cdot 1$ & خير & \\
\hline
\end{tabular}

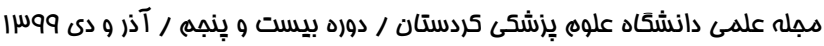




\begin{tabular}{|c|c|c|c|}
\hline $1 F / 4$ & $\Delta q$ & بله & سابقه ماكروزوميا \\
\hline$\Lambda \Delta / 9$ & ral & خير & \\
\hline $4 / 9$ & 19 & بله & سابقه ديابت باردارى \\
\hline $9 \Delta / 4$ & rql & خير & \\
\hline$\cdot / \mathrm{V}$ & $r$ & بله & سابقه فشارخون باردارى \\
\hline $99 / \%$ & $f \cdot V$ & خير ا & \\
\hline$\cdot$ & $\cdot$ & بله & سابقه يره اكلامِسى \\
\hline $1 \cdots$ & $F_{1}$. & خير & \\
\hline $91 / r$ & rol & بله & تهوع و استفراغ \\
\hline rN/A & 109 & خير & \\
\hline 10 & 9 & عدم مصرف & مصرف مكمل \\
\hline $9 \wedge / \Delta$ & $f \cdot F$ & آهن و مولتى ويتامين & \\
\hline $1 / 0$ & 4 & عدم مصرف & مصرف مكمل به طور \\
\hline $\mathrm{V} / / \mathrm{\Delta}$ & rYG & بله & \\
\hline 19 & v^ & خير & \\
\hline$F Q / q$ & $M$ & عدم فعاليت & ميز ان ورزش در طى \\
\hline $\mathrm{MIN}$ & ir. & كمتر از ·r دقيقه & \\
\hline $1 \pi / 4$ & $\Delta \Delta$ & بين ·ب تا ·9 دقيقه & \\
\hline 9 & rV & بيشتر از ·9دقيقه & \\
\hline $9 \vee / 1$ & r^q & زنده & ي ييامد باردارى \\
\hline$r / F$ & 1. & مرده زايى & \\
\hline$\cdot 10$ & r & مركَ نوزاد قبل از ^\روز & \\
\hline$\varphi \mathrm{V} / \mathrm{T}$ & $19 F$ & طيبعى & نو زوز \\
\hline$\Delta r / V$ & Y19 & سزارين & \\
\hline$\Delta \cdot / \mathrm{V}$ & $r \cdot \Lambda$ & دختر & جنسيت \\
\hline $49 / \pi$ & $r \cdot r$ & 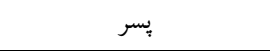 & \\
\hline
\end{tabular}

جدول Y : ميانگين و انحراف معيار متغيرهاى كمى در زنان باردار

\begin{tabular}{|c|c|c|}
\hline انحراف معيار & ميانغين & متغير \\
\hline $9 / \mu r$ & $r \wedge / V I$ & سن (سال) \\
\hline $\mid r / r$ & $V \Delta / Y V$ & وزن آخر با \\
\hline
\end{tabular}




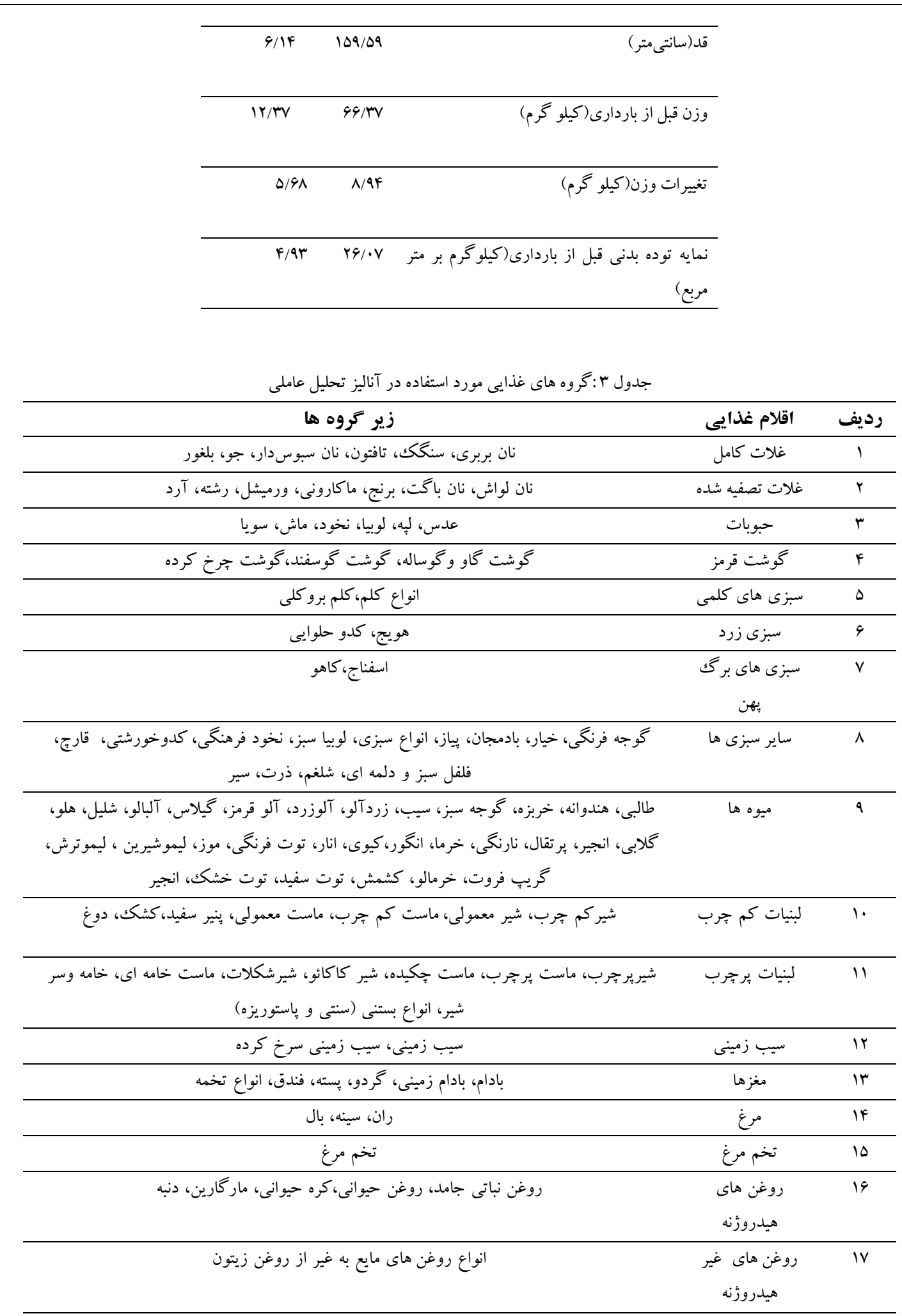

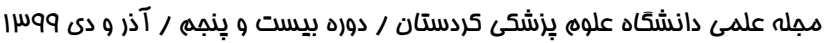


براسى ارتباط بين الكوهاى. VD

\begin{tabular}{|c|c|c|}
\hline زيتون، روغن زيتون & 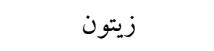 & 11 \\
\hline دل، جگر، قلوه، زبان، مغز، كله و ياجه، سيرابى & كوشت امعاواحشا & 19 \\
\hline ماهى و تن ماهى & ماهى & $r$. \\
\hline إيتزا، ساندويج، كالباس، سوسيس، همبر & فست فود & YI \\
\hline قند، شكر، نبات، آبنبات، حلوا شكرى، انواع شكلات، گز، سوهان، نقل & 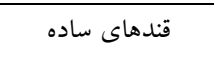 & rr \\
\hline انواع مربا، عسل & 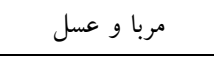 & r \\
\hline بيسكوئيت، شيرينى خشك، شيرينى تر، شكلات، انواع كيك و كلوجه & شيرينى ها & YF \\
\hline جاى & جاى & ro \\
\hline 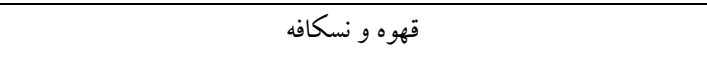 & قهوه & Y4 \\
\hline جييس، يفك & 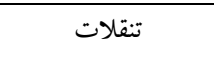 & rV \\
\hline انواع نوشابه، آبميوه صنعتى & نوشيدنى ها & YA \\
\hline نمك & نمك & rq \\
\hline انواع ترشى شور، خيارشور & ترشى & $r$. \\
\hline 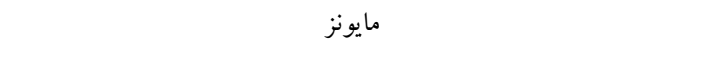 & 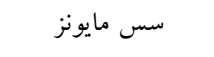 & M \\
\hline كجاب & س كس كجاب & rr \\
\hline آب ميوه ها & آب ميوه & אי \\
\hline آبخوشت & آبخوشت & re \\
\hline
\end{tabular}

سيب زمينى، تنقلات، غلات تصفيه شده، مغزها، روغن هيدروزنه نوشيدنى ها و نمك بيشترين همبستخى مثبت را با

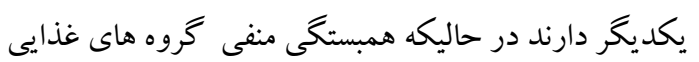
لبنيات كم هرب، زيتون و سبزيجات سبز رنگك در اين الكو

وجود داشت(جدول f).
الكوى غذايى گروه اول در ارتباط با مصرف بالاى گوشت قرمز، تن ماهى، گروه سبزيجات، ميوه، آبميوه، حبوبات

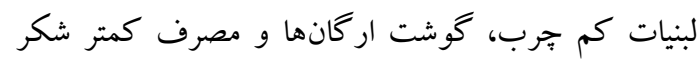
ميباشد. در الكوى غذايى گروه دوم بيشترين بار عاملى مربوط به شكر، عسل و مربا، جاى، ساير سبزيجات، ميوه و

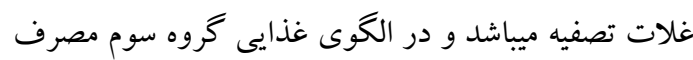

جدولث: الكوهاى غذايى تعيين شده با استفاده از تحليل عاملى در زنان باردار در سه ماهه سوم باردارى

\begin{tabular}{|c|c|c|c|}
\hline الكوى غذايى (كروه سوم) & الكوى غذايى (كروه دوم) & الكوى غذايى كروه اول & كروه هاى غذايع \\
\hline$\cdot$ & .1919 & $-\cdot /$ TFF & شكر \\
\hline - & $\cdot / \Delta \Delta r$ & - & عسل و مربا \\
\hline- & $\cdot / V Y V$ & - & 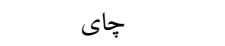 \\
\hline- & - & $\cdot 19 \cdot 0$ & كوشت قرمز \\
\hline- & - & •/OHI & كروه ماهى \\
\hline- & - &.$/ \& \Delta \Lambda$ & سبزيجات زرد رنگك \\
\hline$-\cdot / Y Y$. & - & - / Far & سيزيجات سبزرنگك \\
\hline- & $\cdot / M V I$ & $\cdot / f \mid F$ & ساير سبزيجات \\
\hline
\end{tabular}




\begin{tabular}{|c|c|c|c|}
\hline- & $\cdot / r \cdot 9$ & - /TOF & سبزيجات كلمى \\
\hline- & $\cdot / 491$ & $\cdot / F M$ & ميوه \\
\hline- & - &.$/ . F F$ & آبميوه \\
\hline . rir & . &.$/ 4 q$. & حبوبات \\
\hline$\cdot / r 91$ & - & . MFA & لبنيات كم جرب \\
\hline - & - & $\cdot \mu$ & زيتون \\
\hline ת זM/.- & - & $\cdot / M V$ & كوشت ارگان \\
\hline$\cdot /$ rqf & $\cdot / r \mid A$ & . TAR & مغزها \\
\hline- & "- & . /YYA & غلات كامل \\
\hline . MYY & $\cdot / \mu \cdot \Delta$ & - & غلات تصفيه \\
\hline- & - & - & مرغ \\
\hline.$/ Y 19$ & - & - & تخم مرغ \\
\hline- & - & - & لبنيات برجرب \\
\hline (M4. & - & - & جربى هيدروزنه \\
\hline$-\cdot / r V q$ & $\cdot / T Y V$ & - & جزبى غير هيدروزنه \\
\hline.$/ 010$ & - & - & سيب زمينى \\
\hline$. / T / r$ & - & - & دسر و شيرين ها \\
\hline$\cdot|\Delta \Delta|$ & - & - & تنقلات \\
\hline - /raf & - & - & فست فود \\
\hline - MNY & - & - & نو شيدنى \\
\hline- &.$r \Delta S$ &.$/ Y \Delta Q$ & مايونز \\
\hline- & IYYO & - & سس كجاب \\
\hline$\cdot / Y \wedge \Delta$ &.$/ Y 9 V$ & - & ترشيجات \\
\hline IrFq & - & - & نمك \\
\hline . rar &.$/ Y 19$ & - & آبكوشت \\
\hline
\end{tabular}

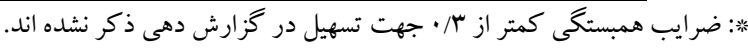

افزايش ويروى از الخوى گروه اول(DBW:OR =1/10 و

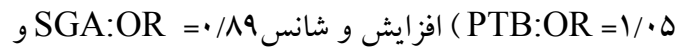
LGA:OR =•/A كاهش مى يابد. الكوى غذايى گروه

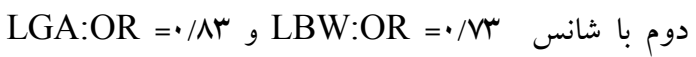

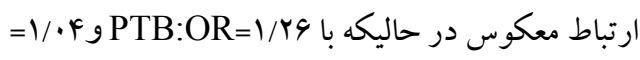
SGA:OR

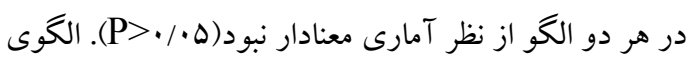
غذايى گروه سوم با شانس SGA ، PTB و

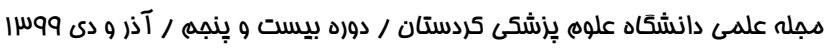

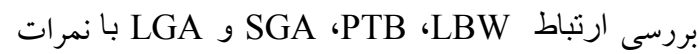
الكوهاى غذايى با استفاده از آناليز ركرسيون لجستيك در جدول ه نشان داده شده است نتايج نشان داد كه يس از تعديل كردن متغيرهاى سن، سطح تحصيلات مادر، سطح

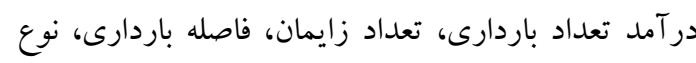
زايمان، وزن مادر در ابتداو آخر باردارى، نمايه توده بدنى و جنسيت نوزاد در مدل آخر، شانس LBW و PTB با بال 
غذايى كروه سوم در مدل هاى I و Y و بصورت Borderline ( $)(\mathrm{OR}=\cdot / 9 \Lambda)$
در مدل خام و مدل ا ارتباط معكوس داشت. در مدل باين ارتباط براى شاخص هاى PTB PGA و LGA بصورت معكوس باقى ماند و تنها شاخص LBW ارتباط مستقيم با با سب نمرات اين الكَ در مدل آخر نشان داد هر جند اين ارتباط معنادار نبود. شاخص LGA بصورت معنادارى با الكوى

جدول ه. ارتباط SGA PTB ، LBW و SGA با نمرات الكوهاى غذايى با استفاده از آناليز رگرسيون لجستيك

\begin{tabular}{|c|c|c|c|c|c|c|c|}
\hline $\begin{array}{l}\text { P- } \\
\text { value }\end{array}$ & $95 \% \mathrm{CI}$ & OR & $\mathrm{SE}$ & $\beta$ & & & الكوهاى غذايى \\
\hline - TYS & $\cdot / M-1 / \Delta V$ & $1 / 19$ & $\cdot / 10$ &.$/ 10$ & مدل خام & LBW & الكوى 1 \\
\hline$\cdot / \Delta Y A$ & $\cdot / \Lambda-1 / \Delta$ & $1 / 1$ &.$/ 19$ & $\cdot / 1$ & مدل & & \\
\hline.$/ 01$. & $\cdot / A-1 / \Delta F$ & $1 / 11$ & .119 & $\cdot / 1$ & مدل r & & \\
\hline$\cdot|\Delta|$ & $\cdot / V q-1 / \Delta q$ & $1 / 10$ & $\cdot / \mathrm{IV}$ & $\cdot / 1$ & مدل r & & \\
\hline$\cdot / 0 \cdot \cdot$ & $\cdot / A Y-I / F V$ & $1 / 1$ & $\cdot / 1 F$ & .1 .9 & مدل خام & РТВ & \\
\hline$\cdot / V 91$ & $\cdot / V V-1 / 41$ & $1 / \cdot 4$ &.$/ 10$ & $\cdot / \cdot F$ & مدل 1 & & \\
\hline - /VYa & $\cdot / V V-1 / 4 r$ & $1 / \cdot 0$ &.$/ 10$ & $.1 \cdot 0$ & مدل r & & \\
\hline$\cdot / N^{r} V$ & $\cdot / V 9-1 / 4 \Delta$ & $1 / \cdot 0$ &.$/ 19$ & $\cdot / \cdot \Delta$ & مدل r & & \\
\hline • & $\cdot / \Delta \Lambda-1 / T \mu$ & $\cdot / A F$ & $\cdot / 19$ &.$- / 19$ & مدل خام & SGA & \\
\hline$\cdot / \Delta Y I$ & $\cdot 19-1 / 79$ & $\cdot / \mathrm{AM}$ &.$/ 19$ & $-\cdot / 1 r$ & مدل 1 & & \\
\hline$\cdot / D F G$ & $\cdot 19-1 / 4$ & $\cdot / \wedge 9$ &.$/ 19$ & $-\cdot / 11$ & مدل r & & \\
\hline$\cdot / 0 \cdot \cdot$ & $\cdot / 09-1 / 49$ & $\cdot / \mathrm{AV}$ &.$/ 19$ & $-\cdot / 1 r$ & مدل r & & \\
\hline$\cdot / T \Delta V$ & $\cdot / \Delta \Delta-1 / 1 \nabla$ & $\cdot / \Lambda$ &.$/ 19$ & $-\cdot / Y 1$ & مدل خام & LGA & \\
\hline$\cdot / Y M A$ & $\cdot / \Delta \Delta-1 / 19$ & $\cdot|\Lambda|$ &.$/ 19$ & $-\cdot / r$ & مدل 1 & & \\
\hline$\cdot / Y \wedge \Lambda$ & $\cdot / \Delta \Delta-1 / 19$ & $\cdot|\Lambda|$ &.$/ 19$ & $-\cdot / r$ & مدل r & & \\
\hline$\cdot / 499$ & $\cdot / \Delta F-1 / 1 \Lambda$ & $\cdot / 1$ & $\cdot / 19$ & $-\cdot / Y 1$ & مدل r & & \\
\hline$\cdot 11 \cdot 4$ & $. / 0-1 / .9$ & $\cdot N r$ & $\cdot / 19$ & $-\cdot / \mu 1$ & مدل خام & LBW & الكوى r \\
\hline.$/ 11$. & $\cdot / \Delta-1 / \cdot V$ & $\cdot N r$ &.$/ 19$ & $-\cdot / \mu$ & مدل 1 & & \\
\hline$\cdot / 111$ & $\cdot / 4 q-1 / \cdot 1$ & $\cdot N r$ & $\cdot / r$ & $-\cdot / \mu 1$ & مدل r & & \\
\hline . /ro & $\cdot / 4 q-1 / 1$ & $\cdot N r$ & $\cdot / r$ & $-\cdot / \pi$ & مدل r & & \\
\hline - /YFV & $\cdot / 19-1 / \Delta \Delta$ & $1 / I V$ & $\cdot / / F$ &.$/ 19$ & مدل خام & PTB & \\
\hline$\cdot / r / 9$ & $\cdot / 199-1 / 09$ & $1 / 19$ & $\cdot / / F$ & $\cdot / 1 \wedge$ & مدل 1 & & \\
\hline$\cdot / Y 19$ & $\cdot \mid 199-1 / 91$ & $1 / r$ & $\cdot / 10$ & $\cdot / 1 \wedge$ & مدل r & & \\
\hline$\cdot / T r$ & $\cdot / 9 Y-1 / V 1$ & $1 / 19$ & $\cdot / 10$ & • & مدل r & & \\
\hline - /9rV & $\cdot|V|-\mid / k r$ & $1 / \cdot 1$ & $\cdot / \mathrm{IV}$ & $\cdot / \cdot 1$ & مدل خام & SGA & \\
\hline$\cdot / 991$ & $\cdot \mid V I-1 / F Y$ & 1 & $\cdot / \mathrm{IV}$ & $\cdot / \cdot$ & مدل 1 & & \\
\hline$\cdot / 9 \Delta r$ & $\cdot / N 1-1 / k r$ & $1 / \cdot 1$ & $\cdot / \mathrm{IV}$ & $\cdot / \cdot 1$ & مدل Y & & \\
\hline
\end{tabular}




\begin{tabular}{|c|c|c|c|c|c|c|}
\hline - /vaf & $\cdot / N r-1 / 4 q$ & $1 / \cdot 4$ & $\cdot / 11$ &.$/ \cdot f$ & مدل r & \\
\hline.$/ 4 \mu$. & $\cdot / \Delta Q-1 / Y F$ & $\cdot / 19$ & $\cdot / 1 \wedge$ &.$- / 1 F$ & LGA & \\
\hline . Ama & $\cdot / \Delta Q-1 / Y \Delta$ & $\cdot / \wedge 9$ &.$/ 1 \wedge$ & $-\cdot / l f$ & مدل & \\
\hline . & $\cdot / \Delta Q-1 / Y F$ & $\cdot / 19$ &.$/ 1 \wedge$ &.$- / 1 F$ & مدل r & \\
\hline$\cdot / M F \Delta$ & $\cdot / \Delta G-1 / Y Y$ & •/A &.$/ 19$ & $-\cdot / 1 \wedge$ & مدل م & \\
\hline$\cdot / \Delta \wedge r$ & $.190-1 / r$ &.$/ 91$ & .119 &.$- \cdot 1 \cdot 9$ & L & الكوى r \\
\hline.$/ 999$ & $\cdot / N-I / r \Lambda$ &.$/ 99$ & $\cdot / \mathrm{IV}$ & $-\cdot / \cdot$ & مدل 1 & \\
\hline - / $/ 499$ & $\cdot / V Y-1 / 4 F$ & $1 / \cdot r$ & $\cdot / \mathrm{VV}$ &.$/ \cdot r$ & مدل r & \\
\hline - / & $\cdot / V-1 / 4 q$ & $1 / \cdot r$ &.$/ 19$ &.$/ \cdot r$ & مدل r & \\
\hline .1949 & $.191-1 / 49$ & $\cdot / 94$ &.$/ 10$ & $-\cdot / \cdot V$ & مدل خام & \\
\hline$\cdot / 941$ & $\cdot / V F-1 / r \Lambda$ & $1 / \cdot 1$ &.$/ 10$ &.$/ 1$ & مدل & \\
\hline - /Ars & $\cdot / V \Delta-1 / F r$ & $1 / \cdot r$ &.$/ 19$ &.$/ . r$ & مدل r & \\
\hline$\cdot / 9 V r$ & $.199-1 / 41$ &.$/ 99$ & $\cdot / / V$ & $-\cdot / \cdot$ & مدل م & \\
\hline$\cdot / V Y I$ & $.199-1 / \pi r$ &.$/ 94$ &.$/ \mathrm{VV}$ & -.1 .9 & مدل خام & \\
\hline$\cdot /$ FAr & $\cdot 19-1 / Y V$ & $\cdot / \mathrm{AV}$ &.$/ 19$ & - & مدل & \\
\hline$\cdot 10 \cdot 9$ & $\cdot 19-1 / 4 \Lambda$ & $\cdot / \Lambda \Lambda$ &.$/ 19$ & $-\cdot / 1 r$ & مدل r & \\
\hline . $/ 014$ & $\cdot / \Delta \Lambda-1 / \Gamma$ & $\cdot / \mathrm{AV}$ & $\cdot / r$ & $-\cdot / 1 r$ & مدل r & \\
\hline .1 .01 & $\cdot / 4 \wedge-1$ & .199 & $\cdot / 1 \wedge$ &.$- / 49$ & مدل خام & \\
\hline.$/ \cdot r v$ & $\cdot / F q-\cdot / q V$ & .190 & $\cdot / r$ & $-\cdot / F r$ & مدل & \\
\hline .1 .49 & $\cdot / 4 q_{-} \cdot / q V$ & .190 & $\cdot / r$ & $-\cdot / F r$ & مدل r & \\
\hline $.1 . \Delta 9$ & $\cdot / 49-1 / \cdot 1$ & $\cdot 191$ & $\cdot / r$ & $-\cdot / \mu \Lambda$ & مدل r & \\
\hline
\end{tabular}

ارتباط با افزايش خطر SGA و دريافت بالاى ميوه، سبزى،

ماهى و مرغ در ارتباط با كاهش خطر SGA مى بـ باشد (r).

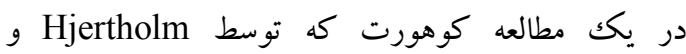

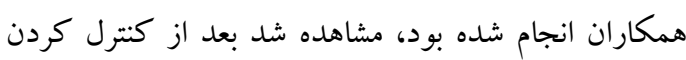

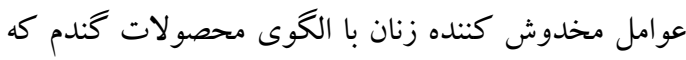
با دريافت بالاى نان، شيرينى، آب ميوه، سبزى و نوشابه

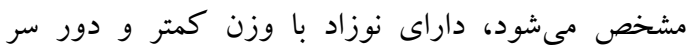

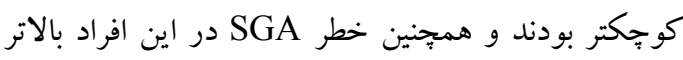

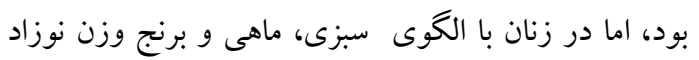

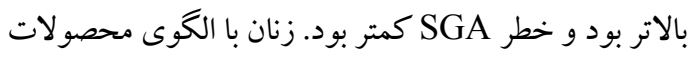

نتايج مطالعه حاضر نشان داد كه شانس PTB, LBW با بان

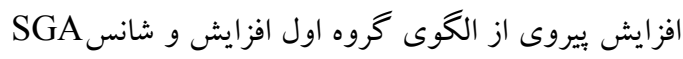

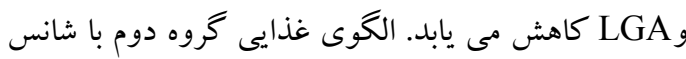

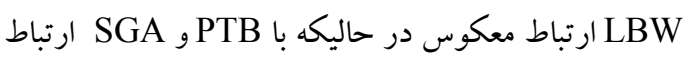

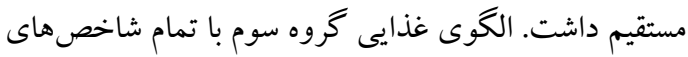

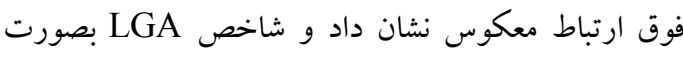
معنادارى با افزايش ييروى از اين الخو كاهش مى مي يابد. در مطالعات انجام شده مشخص گرديد كه استفاده از رزيم

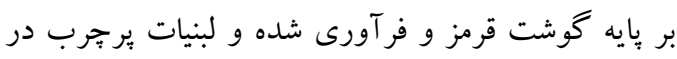


وزن نوزاد تحت تاثير دو فاكتور( طول دوران باردارى و

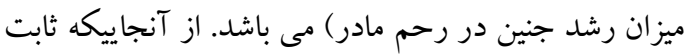

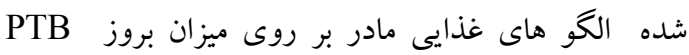

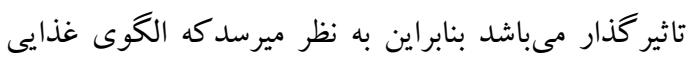

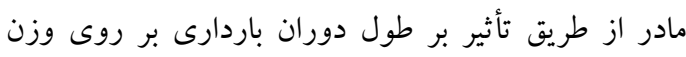
نوزاد وLBW مؤثر ميباشد. در بررسىهاى مرورى انجام شده ،مشخص گرديده كه ارتباط ضعيفى بين الكوهاى

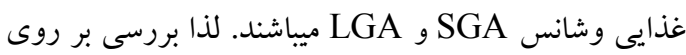
تاثير بين طول مدت باردارى و ييامدهاى آن جهت تاييد فرضيه فوق ضرورى به نظر مى رسد(rV). همسو با نتايج مطالعه حاضر، نتايج مطالعه اى نشان داد كه كه على الرغم

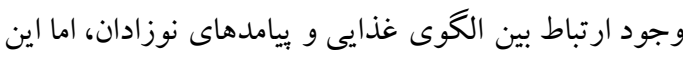

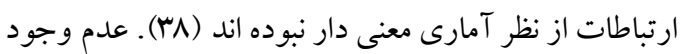

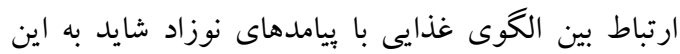

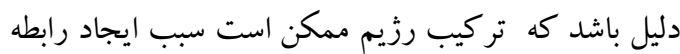

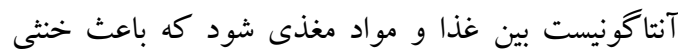

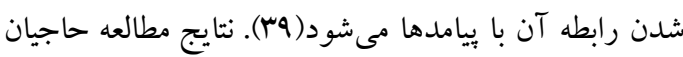

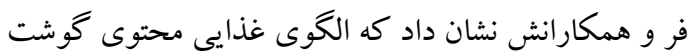

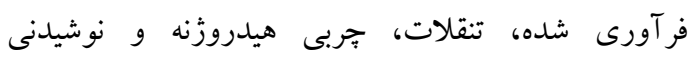

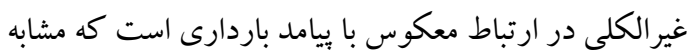
الكوى غذايى گروه سوّم (سيب زمينى، تنقلات، غلات تصفيه شده، روغن هيدروزنه و نوشيدنى ها) در مطالعه

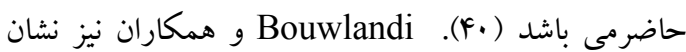

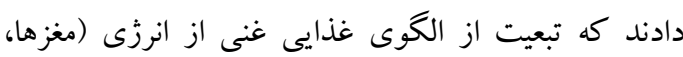

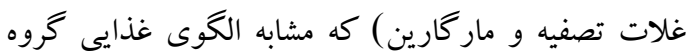
سوم (غلات تصفيه شده، مغزها و روغن هيدروزنه) در مر مابن

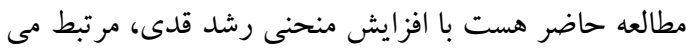

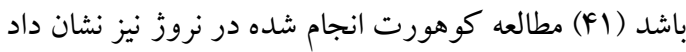
كه الكوى غذايى كم جرب و مقدار جربى اشباع در ارتباط

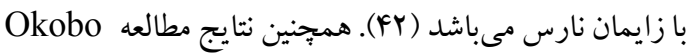
و همكاران بعد از در نظر گرفتن عوامل مخدوش كنيند
كندم معمولاً دجار سوءتغذيه مى شوند و دريافت مواد

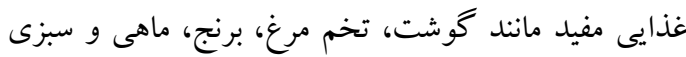

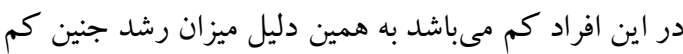

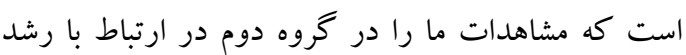

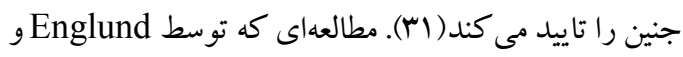
همكاران در نروز انجام شد، مشخص كردكه تولد نوزاد با الكوى غذايى كه محتوى آن شامل مقدار زياد

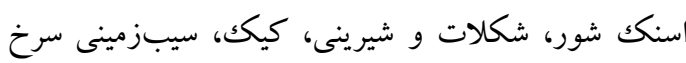

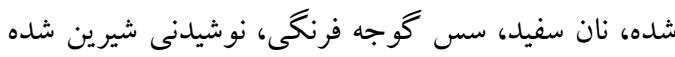

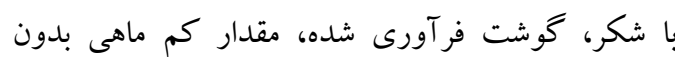
جربى و نان غنى از فيبر مى باشد رابطه معنادار مستقيم

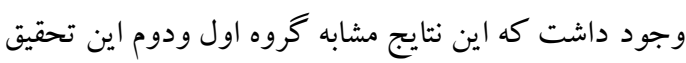

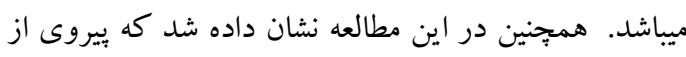

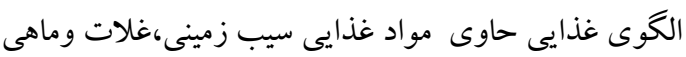

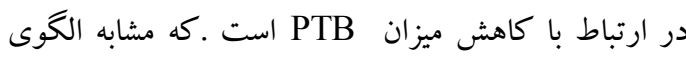

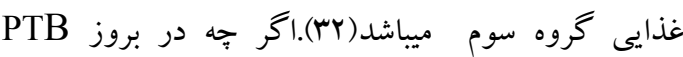

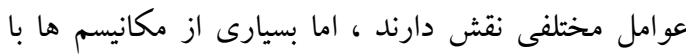

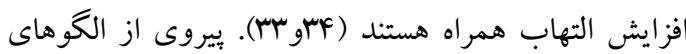

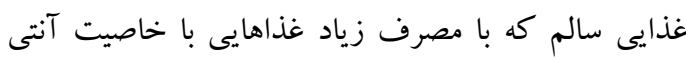
اكسيدانى و ضد التهابى مانند سبزيجات ، ميوه ها ، غلات

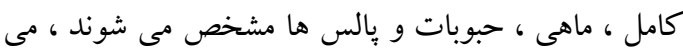

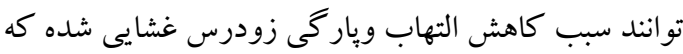
اين امر متعاقبا خطر تولد زودرس را نيز كاهش مى ده دهند (A).

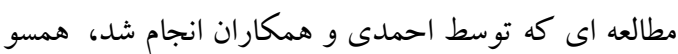
با نتايج مطالعه حاضر نشان داده شد كه الكوى غذايى ناسئ ناسالم

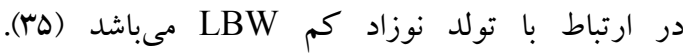
Zulyniak

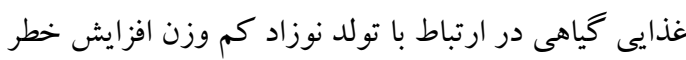
و و كاهش خطر LGA

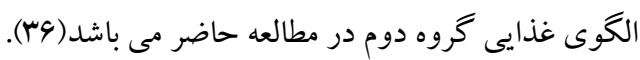




\section{نتيجه كيرى}

نتايج مطالعه حاضر نشان داد كه تبعيت از الكوى غذايى

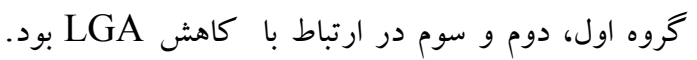

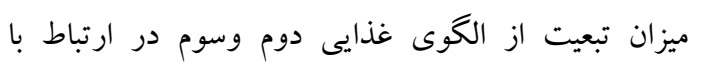

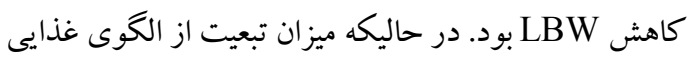

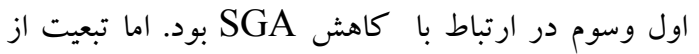

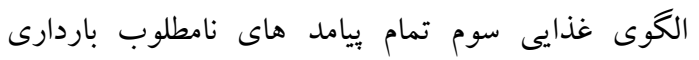

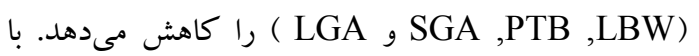
توجه به نتايج مطالعه حاضر به نظر ميرسد كه جهت داشتن

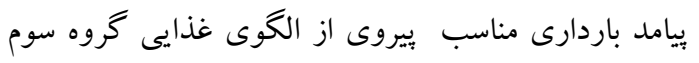

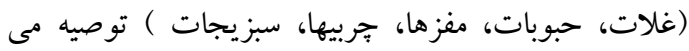

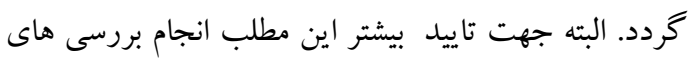
كوهورت بيشنهاد ميكردد.

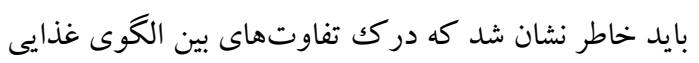
مختلف رايج در ايران ممكن است به تفسير اهميت ياقته هاى

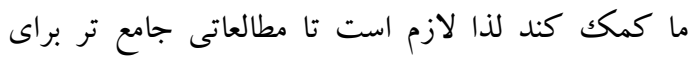
تشخيص بهتر الكوى غذايى در دوران باردارى انجام گيرد.

\section{تشكر وقدردانى}

از كليه همكاران محترم شاغل در مراكز بهداشتى دانشكاه

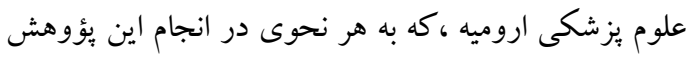

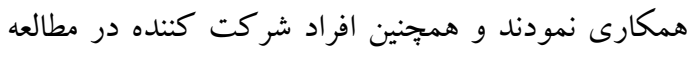
تقدير وتشكر بعمل مى آيد.
نشان داد كه افزايش دريافت انرزى از جربى در ارتباط با

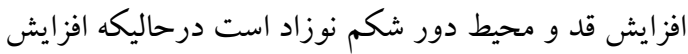

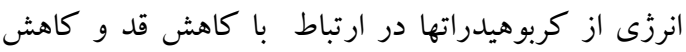
دور سر نوزاد بود كه اين يافته ها بيان ميكند كه تركيب

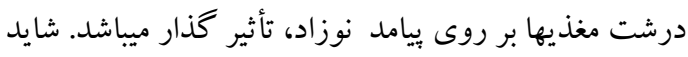
دريافت انرزى از جربى سبب كاهش مصرف بروتئين در متابوليسم و سوخت و ساز بدن ميشود شايد هم بتوان علت

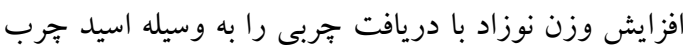
ضرورى توضيح داد، از طرفى با دريافت كافى خربى تربى دريافت ريز مغذيها مانند ويتامين محلول در خروبى بردي نيز افزايش مى يابد كه نقش اين ويتامينها در متابوليسم بدن

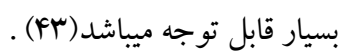
از نقاط قوت مطالعه حاضر، مىتوان به حجم نمونه بالا و مياتدرال،

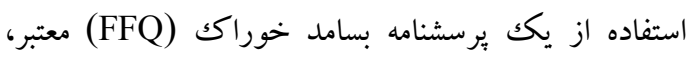
براى ارزيابى دريافت هاى غذايى افراد اشاره كرد. از نقاط

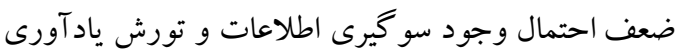

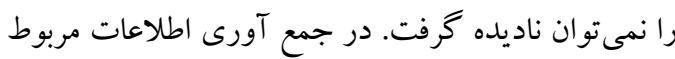

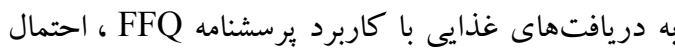

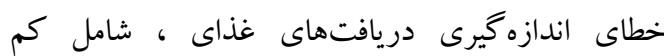

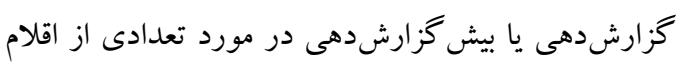

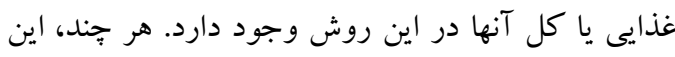

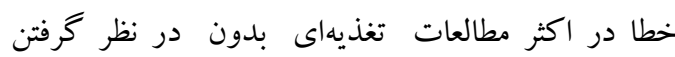
روش به كار رفته مشاهده مى كردد.

1.Barker DJP, Bergmann RL, Ogra PL. The window of opportunity: pre-pregnancy to 24 months of age: Karger Medical and Scientific Publishers; 2008.

2.Azami, M. Darvishi, Z. Borji, M. Sayehmiri, K. The Prevalence of Anemia among Pregnant Women in Iran (2005-2016): A Systematic Review and Meta-Analysis Study. Scientific Journal of School of Public Health and Institute of Public Health Research. 2016; 14(1): 1530 . 
3.Naja F, Nasreddine L, Al Thani AA, Yunis K, Clinton M, Nassar A, et al. Study protocol: Mother and Infant Nutritional Assessment (MINA) cohort study in Qatar and Lebanon. BMC pregnancy and childbirth. 2016; 16:98.

4.Gresham E, Byles JE, Bisquera A, Hure AJ. Effects of dietary interventions on neonatal and infant outcomes: a systematic review and meta-analysis. Amer J Clin Nutr. 2014; 100(5):1298-321.

5.Christian P, Mullany LC, Hurley KM, Katz J, Black RE, editors. Nutrition and maternal, neonatal, and child health. Seminars in Perinatology. 2015; 39(5):361-372.

6.Li N, Liu E, Guo J, Pan L, Li B, Wang P, et al. Maternal prepregnancy body mass index and gestational weight gain on pregnancy outcomes. PloS one. 2013; 8(12):e82310.

7.Pongcharoen T, Gowachirapant S, Wecharak P, Sangket N, Winichagoon P. Pre-pregnancy body mass index and gestational weight gain in Thai pregnant women as risks for low birth weight and macrosomia. Asia Pac J Clin Nutr. 2015; 25(4):1-8.

8.Chia AR, Chen LW, Lai JS, Wong CH, Neelakantan N, van Dam RM, et al. Maternal Dietary Patterns and Birth Outcomes: A Systematic Review and Meta-Analysis. Adv Nutr. 2019; 10(4):685-95.

9.Nouri Saeidlou S, Babaei F, Ayremlou P. Children Malnutrition in Northwestern, Central and Southern Regions of Iran: Does Geographic Location Matter?. Global J of Health Sci. 2014; 6(4). 1-7.

10.Coelho NdLP, Cunha DB, Esteves APP, Lacerda EMdA, Theme Filha MM. Dietary patterns in pregnancy and birth weight. Revista de saude publica. 2015; 49:62-69.

11.Say L, Chou D, Gemmill A, Tunçalp Ö, Moller A-B, Daniels J, et al. Global causes of maternal death: a WHO systematic analysis. The Lancet Global Health. 2014; 2(6): 323-33.

12.Blencowe H, Cousens S, Chou D, Oestergaard M, Say L, Moller A-B, et al. Born too soon: the global epidemiology of 15 million preterm births. Reprod health. 2013; 10(1):S2.

13. Yousefi J, Mirzadeh M, Tavassoli N. To study the prevalence of LBW and to determine the ratio preterm to IUGR during one year in 22 Bahman Hospital in Mashhad. Mashhad Medical Sci J. 2015; 5(1):1-6.

14.Lee AC, Katz J, Blencowe H, Cousens S, Kozuki N, Vogel JP, et al. National and regional estimates of term and preterm babies born small for gestational age in 138 low-income and middle-income countries in 2010. The Lancet Global Health. 2013; 1(1): 26-36.

15.Ramos A, Caimari F, Pujol I, García-Patterson A, Ginovart G, Adelantado J, et al. In women with gestational diabetes mellitus factors influencing growth have a larger effect on placental weight than on birth weight. Eur J Obstet Gynecol Reprod Biol. 2016; 202:60-65.

16.Berggren EK, Stuebe AM, Boggess KA. Excess maternal weight gain and large for gestational age risk among women with gestational diabetes. Am J Perinatol. 2015; 32(3):251-259.

17.Moore VM, Davies MJ, Willson KJ, Worsley A, Robinson JS. Dietary composition of pregnant women is related to size of the baby at birth. J Nutr. 2004; 134(7):1820-6.

18.Tielemans M, Erler N, Leermakers E, van den Broek M, Jaddoe V, Steegers E, et al. A priori and a posteriori dietary patterns during pregnancy and gestational weight gain: the generation R study. Nutrients. 2015; 7(11):9383-99.

19.Valladares E, Ellsberg M, Peña R, Högberg U, Persson LÅ. Physical partner abuse during pregnancy: a risk factor for low birth weight in Nicaragua. Obstet Gynaecol. 2002; 100(4):700-5. 
20.Lu M-S, Chen Q-Z, He J-R, Wei X-L, Lu J-H, Li S-H, et al. Maternal dietary patterns and fetal growth: a large prospective cohort study in China. Nutrients. 2016; 8(5):257.

21.Barnes RA, Edghill N, Mackenzie J, Holters G, Ross GP, Jalaludin BB, et al. Predictors of large and small for gestational age birthweight in offspring of women with gestational diabetes mellitus. Diabetic medicine: a journal of the British Diabetic Association. 2013; 30(9):1040-6.

22.Kim MK, Sasaki S, Sasazuki S, Tsugane S. Prospective study of three major dietary patterns and risk of gastric cancer in Japan. Int J Cancer. 2004; 110(3):435-42.

23.Van Dam RM, Rimm EB, Willett WC, Stampfer MJ, Hu FB. Dietary patterns and risk for type 2 diabetes mellitus in US men. Ann Intern Med. 2002; 136(3):201-9.

24.Hu FB. Dietary pattern analysis: a new direction in nutritional epidemiology. Curr Opin Lipidol. 2002; 13(1):3-9.

25.Naja F, Nasreddine L, Yunis K, Clinton M, Nassar A, Jarrar SF, et al. Study protocol: mother and infant nutritional assessment (MINA) cohort study in Qatar and Lebanon. BMC pregnancy and childbirth. 2016; 16(1):1-12.

26.Timmermans S, Steegers-Theunissen RP, Vujkovic M, den Breeijen H, Russcher H, Lindemans J, et al. The Mediterranean diet and fetal size parameters: the Generation R Study. Br J Nutr. 2012;108(8):1399-409.

27. Organization WH. Global and regional estimates of violence against women: prevalence and health effects of intimate partner violence and non-partner sexual violence: World Health Organization; 2013.

28.Mirmiran P, Esfahani FH, Mehrabi Y, Hedayati M, Azizi F. Reliability and relative validity of an FFQ for nutrients in the Tehran lipid and glucose study. Public Health Nutr. 2010; 13(5):654-62.

29.Heidemann C, Schulze MB, Franco OH, van Dam RM, Mantzoros CS, Hu FB. Dietary patterns and risk of mortality from cardiovascular disease, cancer, and all causes in a prospective cohort of women. Circulation. 2008; 118(3):230-7.

30.Hillesund ER, Bere E, Haugen M, Øverby NC. Development of a New Nordic Diet score and its association with gestational weight gain and fetal growth-a study performed in the Norwegian Mother and Child Cohort Study (MoBa). Public Health Nutr. 2014; 17(9):190918.

31.Hjertholm KG, Iversen PO, Holmboe-Ottesen G, Mdala I, Munthali A, Maleta K, et al. Maternal dietary intake during pregnancy and its association to birth size in rural Malawi: A cross-sectional study. Matern Child Nutr. 2018; 14(1):e12433.

32.Englund-Ögge L, Brantsæter AL, Sengpiel V, Haugen M, Birgisdottir BE, Myhre R, et al. Maternal dietary patterns and preterm delivery: results from large prospective cohort study. Bmj. 2014; 348(1446): 1-8.

33.Goldenberg RL, Culhane JF, Iams JD, Romero R. Preterm birth 1: epidemiology and causes of preterm birth. Lancet. 2008; 371(9606):75-84.

34.Romero R, Chaiworapongsa T, Espinoza J. Micronutrients and Intrauterine Infection, Preterm Birth and the Fetal Inflammatory Response Syndrome. J. Nutr. 2003; 133: 16681673.

35.Ahmadi Taheri S, Ramezani Ahmadi A, Barikani A. Comparison of dietary pattern of pregnancy in mothers with low birth weight and normal birth weight. Iran J Obstet Gynecol Infertil. 2018; 21(1):80-9.

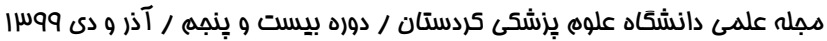


36.Zulyniak MA, de Souza RJ, Shaikh M, Desai D, Lefebvre DL, Gupta M, et al. Does the impact of a plant-based diet during pregnancy on birth weight differ by ethnicity? A dietary pattern analysis from a prospective Canadian birth cohort alliance. BMJ open. 2017; 7(11): 017753.

37.Chia A-R, Chen L-W, Lai JS, Wong CH, Neelakantan N, van Dam RM, et al. Maternal Dietary Patterns and Birth Outcomes: A Systematic Review and Meta-Analysis. Adv Nutr. 2019; 10(4: 685-695.

38. Saunders L, Guldner L, Costet N, Kadhel P, Rouget F, Monfort C, et al. Effect of a M editerranean Diet during Pregnancy on Fetal Growth and Preterm Delivery: Results From a F rench Caribbean Mother-Child Cohort Study (TIMOUN). Paediatr Perinat Epidemiol. 2014; 28(3):235-44.

39.Colón-Ramos U, Racette SB, Ganiban J, Nguyen TG, Kocak M, Carroll KN, et al. Association between dietary patterns during pregnancy and birth size measures in a diverse population in Southern US. Nutrients. 2015; 7(2):1318-32.

40.Hajianfar H, Esmaillzadeh A, Feizi A, Shahshahan Z, Azadbakht L. Major maternal dietary patterns during early pregnancy and their association with neonatal anthropometric measurement. BioMed research international. 2018; 2018.

41.Bouwland-Both M, Steegers-Theunissen R, Vujkovic M, Lesaffre E, Mook-Kanamori D, Hofman A, et al. A periconceptional energy-rich dietary pattern is associated with early fetal growth: the Generation R study. BJOG. 2013; 120(4):435-45.

42.Angueira AR, Ludvik AE, Reddy TE, Wicksteed B, Lowe WL, Layden BT. New insights into gestational glucose metabolism: lessons learned from 21 st century approaches. Diabetes. 2015; 64(2):327-34.

43. Okubo H, Miyake Y, Sasaki S, Tanaka K, Murakami K, Hirota Y, et al. Maternal dietary patterns in pregnancy and fetal growth in Japan: the Osaka Maternal and Child Health Study. Br J Nutr. 2012; 107(10):1526-33. 